Art. \#629, 18 pages, http://www.sajournalofeducation.co.za

\title{
The potential use of mobile technology: enhancing accessibility and communication in a blended learning course
}

\section{Tabisa Mayisela}

Centre for Learning and Teaching Development, Walter Sisulu University, South Africa tmayisela@wsu.ac.za

Mobile technology is increasingly being used to support blended learning beyond computer centres. It has been considered as a potential solution to the problem of a shortage of computers for accessing online learning materials (courseware) in a blended learning course. The purpose of the study was to establish how the use of mobile technology could enhance accessibility and communication in a blended learning course. Data were solicited from a purposive convenience sample of 36 students engaged in the blended learning course. The case study utilized a mixedmethods approach. An unstructured interview was conducted with the course lecturer and these data informed the design of the students' semi-structured questionnaire. It was found that students with access to mobile technology had an increased opportunity to access the courseware of the blended learning course. Mobile technology further enhanced student-to-student and student-to-lecturer communication by means of social networks. The study concludes that mobile technology has the potential to increase accessibility and communication in a blended learning course. Recommendations, limitations of the present study, and suggestions for future research were made.

Keywords: blended learning course, collaboration, communication, computer access, mobile technology, social networks

\section{Introduction}

Technology has become so much part of our lives in the 21 st century that even being fully literate now includes an aspect of 'computer literacy'. The latest explosion in this field is the development of the so-called mobile devices (also referred to as hand-held devices) such as ipads and smartphones. These mobile devices have become affordable and hence are within reach of the masses. They have also introduced a variety of new tools that improve user-friendliness to the extent that they can even support education. Likewise, developments in wireless communication networks such as the $3 \mathrm{G} /$ data card, data bundles, Bluetooth, Wi-Fi and general packet radio service (GPRS) further extend this opportunity for mobile technology users. The term 'mobile technology', as used in this article, includes mobile computers (such as laptops), mobile devices and wireless communication tools.

Research was done at a contact teaching university located in the rural areas of South Africa. The purpose was to establish how the use of mobile technology could enhance accessibility and communication in a blended learning course. In 2009 , the university adopted the blended learning approach whereby some constituents of the 
learning process are facilitated online and some in the classroom (Van der Westhuizen, 2004). Most students at the university normally use computers located in the computer centres to access the online learning materials (courseware) of their blended learning courses. Mobile technology also allowed the students flexible (irrespective of time and location) access to social networks such as Facebook. The Computing dictionary defines social networks as:

"any website designed to allow multiple users to publish content themselves. The information may be on any subject and may be for consumption by (potential) friends, mates, employers, employees, etc. [...who] exchange public or private messages and list other users or groups they are connected to in some way. There may be editorial content or the site may be entirely user-driven" (http://dictionary. reference.com/browse/social+network).

Cobcroft, Towers, Smith \& Axel (2006) claim that mobile technologies within the education context can allow students the opportunity to undertake 'user-led education,' constructing knowledge, and collaborating with peers and learning communities within and beyond the classroom or computer centre. The main problem identified at the university in question was the digital divide. The term 'digital divide' can be loosely defined as any unequal information and communication technology (ICT) access pattern among populations. It exists between countries, developed and developing countries, between ICT users in urban and rural areas, and between ICT users in different socio-economic categories (Broekman, Enslin \& Pendlebury, 2002; Chinn \& Fairlie, 2004; Czerniewicz, Brown, Lee Pan \& Moyo, 2008). Fink and Kenny (2003: 2) interpret the digital divide as:

- A gap in access to use of ICTs - crudely measured by the number and spread of telephones, [smartphones] or web-enabled computers, for instance;

- A gap in the ability to use ICTs - measured by the skills base and the presence of numerous complimentary assets;

- A gap in actual use - the minutes of telecommunications for various purposes, the number and time online of users, the number of internet hosts, and the level of electronic commerce;

- A gap in the impact of use - measured by financial and economic returns.

From this, one can deduce that a digital divide is likely to exist even between students at the same university or more specifically, in a class. The university in question was no exception; the Computer Science students did not have an adequate number of computers in their computer centre. This had a detrimental effect on the students' opportunity to access computers and to make use of the blended learning course. The lecturer and students of this blended learning course explored the use of mobile technology to access the online materials posted in the course and to communicate by means of social networks. The assumption underpinning this study was that access to mobile technology allows the opportunity for use of a blended learning course and 
Facebook. This article also presents the conceptual framework, research methodology, findings and discussion, conclusion, recommendations, limitations of the present study, and a suggestion for future research.

\section{Conceptual framework}

This article focuses on access to ICT in higher education (HE). In this study, ICT includes computers, mobile technology, internet, telecommunications infrastructure and social networks. Although international studies on the access to ICT in HE assume that physical access is in place, this remains a burning issue in the local context (Czerniewicz \& Brown, 2005). This article specifically investigated how access to computers and mobile technology affected the use of the blended learning course and Facebook. Hence the study investigated access to computers and mobile technology, the students' perceptions of access and use of these ICTs, and lastly how these ICTs (social networks) were used for learning and teaching. Czerniewicz \& Brown's (2005) conceptual framework of access to ICT assisted in the description of the Computer Science students' kinds of access to ICT. The framework (as summarised in Table 1) describes what people use, need, and draw on, in order to gain or acquire access to specific ICT uses and practices in terms of technological resources, resources for personal agency, contextual resources and online content resources.

\section{Students' access to ICT}

When Motlik (2008) compared three continents, Asia, North America and Africa, in terms of mobile technology diffusion and internet adoption, it was found that Asia (with China, the greatest producer of mobile phones) was the leading continent in mobile technology diffusion; North America had the highest number of internet adopters and Africa had the lowest mobile technology and internet diffusion rates. According to Sharples, Taylor \& Vavoula (2005), a study conducted at the University of Birmingham revealed that $43 \%$ of students owned laptop computers. This indicates that the developed continents are leading in mobile technology diffusion.

Africa is leapfrogging from an unwired, non-existent e-learning infrastructure to a wireless e-learning infrastructure with seamless integration of online and wireless technologies, and learning management systems (Brown, 2003). Sub-Saharan Africa is also by-passing the fixed network telephony to install mobile phone networks in rural areas (Sharples et al., 2005). A study conducted at three contact teaching South African higher education institutions (HEIs) reported that computer and internet access were evenly distributed among students when they were on campus while access varied according to socio-economic groups and was challenging off-campus. This study further revealed that $98.5 \%$ of the students had mobile phones where $43 \%$ con- 
Table 1 Conceptual framework: resources for access

\begin{tabular}{|c|c|c|c|c|c|c|}
\hline & \multicolumn{2}{|c|}{ Technology } & \multirow{2}{*}{ Personal agency } & \multicolumn{2}{|c|}{ Contextual } & \multirow{2}{*}{ Digital content } \\
\hline & Physical & Practical & & Social & Institutional & \\
\hline Definition & $\begin{array}{l}\text { Tangible } \\
\text { components of } \\
\text { computers and } \\
\text { associated with } \\
\text { telecommunica- } \\
\text { tions infra- } \\
\text { structure }\end{array}$ & $\begin{array}{l}\text { Control over } \\
\text { when and to what } \\
\text { extent computers } \\
\text { are used }\end{array}$ & $\begin{array}{l}\text { Person's } \\
\text { disposition } \\
\text { towards using } \\
\text { computers as well } \\
\text { as their aptitude }\end{array}$ & $\begin{array}{l}\text { Interest and } \\
\text { support received } \\
\text { from a } \\
\text { community social } \\
\text { network }\end{array}$ & $\begin{array}{l}\text { Integration of } \\
\text { technology into } \\
\text { the institution }\end{array}$ & $\begin{array}{l}\text { Availability of } \\
\text { suitable digital } \\
\text { material online }\end{array}$ \\
\hline Indicators & $\begin{array}{l}\text { Location } \\
\text { Availability } \\
\text { Adequacy }\end{array}$ & $\begin{array}{l}\text { Time } \\
\text { Autonomy }\end{array}$ & $\begin{array}{l}\text { Interest } \\
\text { Purpose } \\
\text { Experience } \\
\text { Knowledge } \\
\text { Training } \\
\text { Skills }\end{array}$ & $\begin{array}{l}\text { Support } \\
\text { Networks }\end{array}$ & $\begin{array}{l}\text { Extent } \\
\text { Policy } \\
\text { Support } \\
\text { Intention }\end{array}$ & $\begin{array}{l}\text { Relevance } \\
\text { Local } \\
\text { Production } \\
\text { Language }\end{array}$ \\
\hline
\end{tabular}

Adopted from Czerniewicz \& Brown (2005) 
veniently used them to access the internet when they were off-campus. The students used computers and mobile phones to communicate with their lecturers and tutors by e-mail. They further participated in online discussions with peers (Czerniewicz et al., 2008).

\section{Communication and collaboration in a learning environment}

Students who are traditionally used to face-to-face instruction may feel frustrated if the instructor is absent when they want to appeal to him or her to explain learning content (Meier, 2007). The problem of a shortage of computers contributed to the students' limited access to the learning management system (LMS) that has communication tools and e-mail. This meant that communication was limited outside class and tutorial sessions. Interest in the use of social networks then rose when the lecturer noticed that students made use of Facebook on their smartphones. The use of Facebook for communication and collaboration was then explored.

A study conducted by Mentz \& Goosen (2007) found that collaboration allowed learners the opportunity to: share ideas and tips to solve problems; explain the courserelated problems to one another; show one another their mistakes; and in some instances the expert learners could assist the bad performers. Social networks create a learning environment that allows student-centred learning, and end-user content creation and sharing (Cochrane, 2009). In a study conducted at the University of Canterbury, New Zealand, the Geophysical Fluid Dynamics students who used Facebook in the classroom reported that Facebook gave them an opportunity to receive positive comments from peers (McDonald, 2009). The above literature study indicates that social networks have a potential of supporting communication and collaboration in a learning environment.

The potential use of mobile technology and social networks at the university in question In this case study, the students were engaged in a blended learning course with courseware placed on a LMS, Blackboard. The Java Programming (a Computer Science Course) class had 36 registered students. The lecturer had uploaded materials such as the learner guide, lecture notes, group work and the solutions to all tests and assignments on Blackboard. The departmental computer centre had only a few working computers which made it practically impossible for students to access a computer every day of the week. Even when the Centre for Learning and Teaching Development (CLTD) e-learning centre was available, the students had to book in advance, and had to compete with the university student population for access to the centre. Due to the shortage of computers, some of the students who had access to laptops with internet connectivity used them in the residences and at other locations to access the courseware.

At the same time, communication with students outside the class also became 
almost impossible. The lecturer continuously observed in class that about six students had smartphones (mobile phones that can connect to the internet), and that these students spent a considerable amount of time on Facebook. Also mindful of the fact that those students who had laptops with internet connectivity would also be able to participate on Facebook anytime, it became convenient for him to explore the use of Facebook to communicate with the students. He then created a private Facebook page called CSI2101 Java Programming. Some students without mobile devices felt that they were being disadvantaged. The lecturer therefore, used Facebook as a noticeboard rather than an e-learning platform and still duplicated all the notices posted on Facebook on the LMS. In some occasions, the lecturer would discuss the solutions to problems posted by students on Facebook. Students also discussed among themselves and shared information on Facebook. It is hoped that, ultimately, more students will have access to mobile devices.

\section{Methodology}

The study followed a case study design. According to Nieuwenhuis (2010:75), case study research is "aimed at gaining greater insight and understanding of the dynamics of a specific situation". This case study utilised a mixed methods approach. Mixed methods research involves the process of collecting, analysing, and mixing qualitative and quantitative data within a single or multiple studies in order to understand a research problem more completely (Creswell \& Plano Clark, 2007). An unstructured interview was conducted with the course lecturer in order to understand how mobile technology and Facebook were used in the blended learning course. Data from the interview informed the design of the students' semi-structured questionnaire that was used to ascertain from the students how these tools had improved the accessibility of learning materials, and their communication in the course. To maximise validity, the questions were developed based on Czerniewicz \& Brown's (2005) framework of access to ICT. The questionnaire included closed-ended questions such as multiple choices, yes/no, and Likert-scale questions, and open-ended questions.

A purposive convenience sample of 36 Java Programming students was used. The sampling was purposive as these students already made use of mobile technology and Facebook in this blended learning course. The sampling also proved to be convenient because there were no costs involved for data collection, and as the questionnaires were administered face-to-face, there was a possibility that most of the questionnaires would be returned. Using the target population as sample has contributed to reliability in the case study.

For ethical reasons, the students were called together at the same time and the purpose of the research was explained to them. Students were asked to voluntarily participate in answering the questionnaire and were also assured that their responses would remain anonymous and dealt with confidentially. Of the 36 students who were 
given the questionnaire, 30 students $(83 \%)$ responded. The students' responses to the closed-ended questions were analysed using the Statistical Package (SPSS). Verbatim quotations were used to present the qualitative data from the participants. The quantitative data were summarized in the form of tables. The variables were analysed independently; otherwise cross-tables were used to deduce meaning between related variables.

\section{Findings and discussion}

This section describes findings and discusses the Java Programming students' access to ICT.

\section{Need for use of ICT}

When students were asked about the frequency of their class attendance, they responded as in Table 2, and had various reasons for missing classes.

Table 2 How often students attend classes $v s$ reasons for missing classes

\begin{tabular}{lcccc}
\hline \multirow{2}{*}{ Reason for missing classes } & \multicolumn{4}{c}{ How often do you attend classes? } \\
\cline { 2 - 5 } & Always & Often & Seldom & Total \\
\hline Family commitment & 0 & 1 & 0 & 1 \\
Time-table clashes & 0 & 13 & 0 & 13 \\
Sick & 0 & 4 & 0 & 4 \\
Live off-campus & 0 & 1 & 1 & 2 \\
Not applicable & 10 & 0 & 0 & 10 \\
Total & 10 & 19 & 1 & 30 \\
\hline
\end{tabular}

These data revealed that some students sometimes missed classes. The use of a blended learning course has therefore provided a potential opportunity for these students, together with those who never missed classes, to access courseware outside the class. This would provide expanded opportunities and individualised learning experiences (Czerniewicz \& Brown, 2005) as students could go back on attended classes or those who missed classes, for one reason or another, would have an opportunity to catch up on the missed classes.

Access to ICT

Availability and location

The identified problem was inadequate physical access to computers. In order to determine the practical conditions of access at the students' own time, the students were asked whether they had access to a computer outside class and tutorial sessions. 
Twenty-six of the 30 respondents said that they had access to computers and four did not. Of those with access, 13 accessed a computer from the Departmental centre, four from the CLTD e-Learning centre, four from home, 11 from their rooms and two at a friend's place. The data indicated that some of the 26 students had more than one location to access a computer. This implied that some students could make use of computers located at locations other than the computer centre at a time convenient to them.

As this is a blended learning course with a web-based LMS and the fact that the study also explored the use of Facebook, it was important to find out whether the computers accessed by students outside class sessions had internet connectivity. The data revealed that 14 of the respondents had computers with internet connectivity whereby they connected by means of a network interface card and wireless communication networks such as modems, data/3G cards, data bundles, or GPRS (Table 3 ).

Table 3 How students connected to the internet

\begin{tabular}{lcccc}
\hline Connection to the internet & Frequency & Percentage & $\begin{array}{c}\text { Valid } \\
\text { percentage }\end{array}$ & $\begin{array}{c}\text { Cumulative } \\
\text { percentage }\end{array}$ \\
\hline Network interface card & 7 & 23.3 & 23.3 & 23.2 \\
Modem & 1 & 3.3 & 3.3 & 26.7 \\
Data/3G card & 2 & 6.7 & 6.7 & 33.3 \\
Mobile phone data bundles & 2 & 6.7 & 6.7 & 40.0 \\
GPRS & 2 & 6.7 & 6.7 & 46.7 \\
Not applicable & 16 & 53.3 & 53.3 & 100.0 \\
& & & & \\
Total & 30 & 100.0 & 100.0 & \\
\hline
\end{tabular}

Those who connected by means of the network interface card were most probably those who accessed the internet from the computer centres. The data revealed that seven of those respondents, who accessed computers from locations other than the computer centres, connected by means of wireless communication networks, meaning that they were able to access the courseware and Facebook at their convenient location and time. The other 12 ( 4 had indicated that they did not have access to computers) respondents' computers did not have internet connectivity. It is therefore, important for institutional decision-makers to note that some students have computers on campus but do not have mobile communication networks. Other desktop studies at the university in question also indicated this: students with laptops queued for any network point they found on campus to connect to the internet.

\section{Frequency of use}

Czerniewicz and Brown (2005:3) emphasise that "access and use are closely interrelated: access to resources and the use of resources are inter-dependent". The question 
to be addressed here was: how frequently did students use courseware and Facebook as a result of having access to ICT? It was crucial to first investigate the types of computers that students had access to and which ones they used to access courseware and Facebook. This classification was important for institutional decision-makers who may be considering technological investment strategies for enhanced communication and access to courseware. To address the above question, access to courseware was tackled first. Students were asked to indicate the type of computer they used to access the courseware. They responded as illustrated in Tables 4(a), 4(b) and 4(c).

Table 4(a) Students who accessed courseware using a desktop

\begin{tabular}{lcccc}
\hline Access using a desktop & Frequency & Percentage & $\begin{array}{c}\text { Valid } \\
\text { percentage }\end{array}$ & $\begin{array}{c}\text { Cumulative } \\
\text { percentage }\end{array}$ \\
\hline Yes & 13 & 43.3 & 43.3 & 43.3 \\
No & 17 & 56.7 & 56.7 & 100.0 \\
Total & 30 & 100.0 & 100.0 & \\
\hline
\end{tabular}

Table $\mathbf{4 b}$ ) Students who accessed courseware using a laptop

\begin{tabular}{lcccc}
\hline Access using a laptop & Frequency & Percentage & $\begin{array}{c}\text { Valid } \\
\text { percentage }\end{array}$ & $\begin{array}{c}\text { Cumulative } \\
\text { percentage }\end{array}$ \\
\hline Yes & 14 & 46.7 & 46.7 & 46.7 \\
No & 16 & 53.3 & 53.3 & 100.0 \\
Total & 30 & 100.0 & 100.0 & \\
\hline
\end{tabular}

Table 4(c) Students who accessed courseware using a mobile device

\begin{tabular}{ccccc}
\hline Access using a mobile device & Frequency & Percentage & $\begin{array}{c}\text { Valid } \\
\text { percentage }\end{array}$ & $\begin{array}{c}\text { Cumulative } \\
\text { percentage }\end{array}$ \\
\hline Yes & 5 & 16.7 & 16.7 & 16.7 \\
No & 25 & 83.3 & 83.3 & 100.0 \\
Total & 30 & 100.0 & 100.0 & \\
\hline
\end{tabular}

In contrast to the other two means of access, only five respondents accessed courseware using mobile devices. This difference may be influenced by the fact that, as the lecturer said: "... when the students considered using mobile phones to access Blackboard, it took some time to log on". One student also said: "It was difficult to 
access Blackboard on my smartphone". This is not unique as Chen \& Kinshuk (2005) also identified limitations of the use of mobile devices over the desktop computer setup in education. The bandwidth of wireless networks is relatively low, and mobile devices have very small screens, display mono-colour, have a limited processing and memory capacity and also limited input facilities (Chen \& Kinshuk, 2005). Therefore, in order to effectively deliver the educational services wirelessly to the mobile devices, it is necessary to choose a wireless development platform that specifically supports these devices and generates portable content that is suitable to be delivered to these devices (Chen \& Kinshuk, 2005). This implies that it is important for the institutional decisionmakers to ensure that Blackboard is easily accessible on smartphones in order to enhance easy access to courseware.

At the same time, it was also interesting for the study to find out how frequently the students accessed the courseware using the different types of computers. They were then asked to rate, on a Likert scale, how frequently they interacted with the courseware. In ascending order, $77 \%$ of those with access to desktops, $79 \%$ of those with access to laptops and $80 \%$ of those with access to mobile devices often accessed courseware at a time convenient to them.

Tables 5(a), 5(b), and 5(c) illustrate cross-tabulations of the students' frequency of access and the device they used to access courseware.

Table 5(a) How often students interacted with courseware vs access using a desktop

\begin{tabular}{lccc}
\hline & \multicolumn{4}{c}{ Access using a desktop } \\
\cline { 2 - 4 } How often do you interact with courseware? & Yes & No & Total \\
\cline { 2 - 4 } & 5 & 6 & 11 \\
Very often & 5 & 7 & 12 \\
Often & 3 & 2 & 5 \\
Seldom & 0 & 2 & 2 \\
Never & 13 & 17 & 30 \\
Total & 13 & \\
\hline
\end{tabular}

Table 5b) How often students interacted with courseware vs access using a laptop

\begin{tabular}{lccc}
\hline & \multicolumn{3}{c}{ Access using a laptop } \\
\cline { 2 - 4 } How often do you interact with courseware? & Yes & No & Total \\
\cline { 2 - 4 } & 7 & 4 & 11 \\
Very often & 4 & 8 & 12 \\
Often & 1 & 4 & 5 \\
Seldom & 2 & 0 & 2 \\
Never & & & 30 \\
Total & 14 & 16 & \\
\hline
\end{tabular}


Table 5(c) How often students interacted with courseware vs access using a mobile device

\begin{tabular}{lcrc}
\hline \multirow{2}{*}{ How often do you interact with courseware? } & \multicolumn{3}{c}{ Access using a mobile device } \\
\cline { 2 - 4 } & Yes & No & Total \\
\hline Very often & 2 & 9 & 11 \\
Often & 2 & 10 & 12 \\
Seldom & 1 & 4 & 5 \\
Never & 0 & 2 & 2 \\
Total & 5 & 25 & 30 \\
\hline
\end{tabular}

These data indicated that students with mobile devices and laptops had an increased opportunity to interact with courseware. Those students who accessed a computer at computer centres still had a limited opportunity to interact with courseware as they had to share the computer time with the other university students. These data revealed that a digital divide existed between those students who had access to mobile technology and those who did not. This confirmed Fink \& Kenny's (2003) view of the existence of a digital divide in Southern Africa whereby some people still fail to access mobile technology.

It is however important to note that even if data from the university in question indicated that five respondents accessed courseware using mobile devices, Table 6 indicates that generally, some students perceived that mobile devices extended the opportunity to interact with courseware.

Table 6 Mobile devices extended the opportunity to interact with courseware

\begin{tabular}{lccrr}
\hline & Frequency & Percentage & $\begin{array}{c}\text { Valid } \\
\text { percentage }\end{array}$ & $\begin{array}{c}\text { Cumulative } \\
\text { percentage }\end{array}$ \\
\hline Missing & 2 & 6.7 & 6.7 & 6.7 \\
Strongly disagree & 3 & 10.0 & 10.0 & 16.7 \\
Disagree & 1 & 3.3 & 3.3 & 20.0 \\
Uncertain & 3 & 10.0 & 10.0 & 30.0 \\
Agree & 6 & 20.0 & 20.0 & 50.0 \\
Strongly agree & 15 & 50.0 & 50.0 & 100.0 \\
& & & & \\
Total & 30 & 100.0 & 100.0 & \\
\hline
\end{tabular}

This indicated that, given a chance, the students would make use of mobile devices to access courseware. Their responses to open-ended questions confirmed this. When asked to comment and make suggestions about accessibility of computers and 
mobile devices for their studies, they gave some positive comments. One respondent said: "Accessibility to these devices was helpful as I was able to work on my course". Another one went on to say: "We have got very few computers so mobile devices have been a great tool for me to access applications like the internet." Furthermore, 23 respondents felt that, in general, mobile technology improved their learning experience. For the scope of this study, the students' learning and the availability of suitable digital content were not investigated; these have been recommended for further research.

To further respond to the question of frequency of use, the use of Facebook was subsequently investigated. When students were asked from where they had accessed Facebook, they indicated that they used computers (desktops and laptops) and mobile phones (Tables 7(a) and 7(b)).

Table 7(a) Students who accessed Facebook from a computer

\begin{tabular}{lcccc}
\hline & Frequency & Percentage & $\begin{array}{c}\text { Valid } \\
\text { percentage }\end{array}$ & $\begin{array}{c}\text { Cumulative } \\
\text { percentage }\end{array}$ \\
\hline Yes & 24 & 80.0 & 80.0 & 80.0 \\
No & 6 & 20.0 & 20.0 & 100.0 \\
Total & 30 & 100.0 & 100.0 & \\
\hline
\end{tabular}

Table $7 b)$ Students who accessed Facebook from a mobile device

\begin{tabular}{lcccc}
\hline & Frequency & Percentage & $\begin{array}{c}\text { Valid } \\
\text { percentage }\end{array}$ & $\begin{array}{c}\text { Cumulative } \\
\text { percentage }\end{array}$ \\
\hline Yes & 19 & 63.3 & 63.3 & 63.3 \\
No & 11 & 36.7 & 36.7 & 100.0 \\
Total & 30 & 100.0 & 100.0 & \\
\hline
\end{tabular}

This means that more students (19) had access to mobile phones, particularly smartphones, than the six students who the lecturer saw in class. Twenty respondents perceived that mobile technology extended the opportunity to participate in the Course Facebook page. They expressed their perceptions as illustrated in Table 8 .

The framework emphasises that interest and attitude towards using computers for learning and teaching influences the way academic or students meaningfully engage with ICT for such practices. 
Table 8 Mobile technology extended the opportunity to participate in Facebook

\begin{tabular}{lcccc}
\hline & Frequency & Percentage & $\begin{array}{c}\text { Valid } \\
\text { percentage }\end{array}$ & $\begin{array}{c}\text { Cumulative } \\
\text { percentage }\end{array}$ \\
\hline Missing & 2 & 6.7 & 6.7 & 6.7 \\
Strongly disagree & 4 & 13.3 & 13.3 & 20.0 \\
Uncertain & 4 & 13.3 & 13.3 & 33.3 \\
Agree & 11 & 36.7 & 36.7 & 70.0 \\
Strongly agree & 9 & 30.0 & 30.0 & 100.0 \\
& & & & \\
Total & 30 & 100.0 & 100.0 & \\
\hline
\end{tabular}

\section{Interpreting findings about access to ICT}

The data revealed that some students accessed computers at a convenient location and time. Furthermore, students frequently accessed courseware and Facebook using laptops and mobile devices, in contrast to desktop computers. Students also perceived that mobile devices could improve access to courseware (21) and Facebook (20), and this was also supported by responses to open-ended questions. As, according to the framework, access to ICT is considered in relation to use, and investigated in terms of purpose for use, availability, convenience (location and time), frequency and perception of access, these findings suggest that the students had more access to mobile devices than desktop computers located in the computer centres. The institutional decisionmakers need to consider mobile technology as a potential solution to the problem of the shortage of computers.

\section{Use of ICT for communication and collaboration}

As the use of ICT for communication is also a point of interest in this study, students were asked which e-mail account they used to communicate with their lecturer or peers. The data revealed that eight made use of the University e-mail, 10 used their personal e-mail, nine used both, while three responded that they never used e-mail for communication in the course. Twenty-eight of the respondents participated further in the course Facebook page.

When asked how often they communicated with their lecturer and peers on Facebook, they responded as in Tables 9(a) and 9(b).

When asked (selecting from a multiple response question) for what purpose they had used Facebook; 12 of the respondents said that they used Facebook to ask questions they hadn't thought of in class, 10 asked questions they were shy to ask in class, 13 saw Facebook as a platform that allowed them to share information with peers, and 17 responded that it allowed them to interact with their lecturer even after hours. The lecturer had also attested to this by saying: "Students had access to me all the time 
even at night around $10 \mathrm{~h} 00$, getting answers to their questions immediately, clearing their doubts with me anytime without waiting to meet me physically".

Table 9(a) How often students communicated with their lecturer on Facebook

\begin{tabular}{lcccr}
\hline & Frequency & Percentage & $\begin{array}{c}\text { Valid } \\
\text { percentage }\end{array}$ & $\begin{array}{c}\text { Cumulative } \\
\text { percentage }\end{array}$ \\
\hline Missing & 1 & 3.3 & 3.3 & 3.3 \\
Very often & 8 & 26.7 & 26.7 & 30.0 \\
Often & 12 & 40.0 & 40.0 & 70.0 \\
Seldom & 7 & 23.3 & 23.3 & 93.3 \\
Never & 2 & 6.7 & 6.7 & 100.0 \\
& & & & \\
Total & 30 & 100.0 & 100.0 & \\
\hline
\end{tabular}

Table 9b) How often students communicated with their peers on Facebook

\begin{tabular}{lcccc}
\hline & Frequency & Percentage & $\begin{array}{c}\text { Valid } \\
\text { percentage }\end{array}$ & $\begin{array}{c}\text { Cumulative } \\
\text { percentage }\end{array}$ \\
\hline Missing & 1 & 3.3 & 3.3 & 3.3 \\
Very often & 12 & 40.0 & 40.0 & 43.3 \\
Often & 12 & 40.0 & 40.0 & 83.3 \\
Seldom & 3 & 10.0 & 10.0 & 93.3 \\
Never & 2 & 6.7 & 6.7 & 100.0 \\
& & & & \\
Total & 30 & 100.0 & 100.0 & \\
\hline
\end{tabular}

When asked to rate on a Likert scale whether Facebook had improved online communication in the course, 21 of the respondents responded positively (Table 10).

Table 10 Facebook improved online communication in the course

\begin{tabular}{lcccc}
\hline & Frequency & Percentage & $\begin{array}{c}\text { Valid } \\
\text { percentage }\end{array}$ & $\begin{array}{c}\text { Cumulative } \\
\text { percentage }\end{array}$ \\
\hline Missing & 3 & 10.0 & 10.0 & 10.0 \\
Strongly disagree & 2 & 6.7 & 6.7 & 16.7 \\
Disagree & 1 & 3.3 & 3.3 & 20.0 \\
Uncertain & 3 & 10.0 & 10.0 & 30.0 \\
Agree & 10 & 33.3 & 33.3 & 63.3 \\
Strongly agree & 11 & 36.7 & 36.7 & 100.0 \\
& & & & \\
Total & 30 & 100.0 & 100.0 & \\
\hline
\end{tabular}


This is consistent with the view that social networks, such as Facebook, enhance collaboration and information sharing (McDonald, 2009; Cochrane, 2009). From the lecturer's perspective, access to mobile technology improved the students' participation in the course and afforded them an increased opportunity for mentoring. However, he reported, "the only disadvantage of this method of teaching is that it keeps the lecturer so busy because you do not want to disappoint your students, and using my smartphone made it impossible to miss an email, a Facebook message or a normal SMS from the students". He also said that the use of Facebook improved the way students prepared for classes; "they participated with more enthusiasm in my classes because they already knew what they would discuss and at what time; this has further improved their performance in tests". The student data confirmed the lecturer's statement that Facebook increased their participation in the course (Table 11).

Table 11 Facebook increased participation

\begin{tabular}{lcccc}
\hline & Frequency & Percentage & $\begin{array}{c}\text { Valid } \\
\text { percentage }\end{array}$ & $\begin{array}{c}\text { Cumulative } \\
\text { percentage }\end{array}$ \\
\hline Missing & 3 & 10.0 & 10.0 & 10.0 \\
Strongly disagree & 2 & 6.7 & 6.7 & 16.7 \\
Disagree & 1 & 3.3 & 3.3 & 20.0 \\
Uncertain & 5 & 16.7 & 16.7 & 36.7 \\
Agree & 9 & 30.0 & 30.0 & 66.7 \\
Strongly agree & 10 & 33.3 & 33.3 & 100.0 \\
Total & 30 & 100.0 & 100.0 & \\
\hline
\end{tabular}

Eighteen of the respondents were also comfortable to say that Facebook improved their learning experience (Table 12).

Table 12 Facebook improved my learning experience

\begin{tabular}{lcccc}
\hline & Frequency & Percentage & $\begin{array}{c}\text { Valid } \\
\text { percentage }\end{array}$ & $\begin{array}{c}\text { Cumulative } \\
\text { percentage }\end{array}$ \\
\hline Missing & 4 & 13.3 & 13.3 & 13.3 \\
Strongly disagree & 2 & 6.7 & 6.7 & 20.0 \\
Disagree & 1 & 3.3 & 3.3 & 23.2 \\
Uncertain & 5 & 16.7 & 16.7 & 40.0 \\
Agree & 11 & 36.7 & 36.7 & 76.7 \\
Strongly agree & 7 & 23.3 & 23.3 & 100.0 \\
Total & & & & \\
\hline
\end{tabular}


These data revealed that the use of Facebook improved online communication and increased participation in the course. According to the lecturer, this may possibly have contributed to improved test performance. Assessing learning was beyond the scope of this study.

The students were also asked to give comments and suggestions on communication aspects in their course. Twenty of the respondents felt that Facebook was a good tool that kept them updated with the course. One student also said: "Facebook helps because we don't get to attend class as they clash, so using Facebook helps very much". Another said: "It has been a useful tool, we have access to the lecturer anytime to ask questions and these interactions can be viewed by anyone; some issues that I had not realised were addressed through other students asking questions". This concurs with what the lecturer had said; he responded to the students' questions or other students responded as they saw the question on Facebook (Figure 1). Three respondents were also of the view that the use of Facebook should be allowed anytime of the day, in the computer centres (which is currently not the situation). Two students said that they did not like the idea of Facebook as their mobile phones did not allow access to Facebook. As the lecturer was also aware of this problem, he also duplicated the announcements he sent on Facebook on Blackboard. Figure 1 is a screenshot of the students sharing information on Facebook.

\section{Student \\ CSI2101 CLASS,THTS D SCOPE 4 D TEST ON EXCEPTION HANDLING about a month ago - Like · Comment · Subscribe}

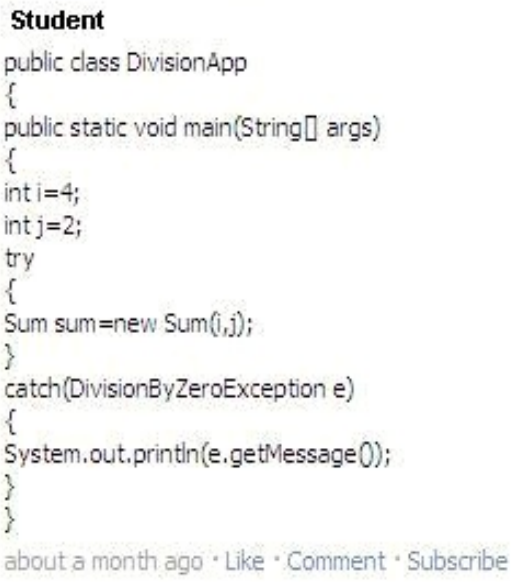

Figure 1 A screenshot of a student sharing a solution to a Java program on Facebook 
Generally, these findings revealed that the use of social networks enhanced communication and collaboration in the blended learning course.

\section{Conclusion}

The problem that this study attempted to investigate was the access to computers that the Computer Science students who implemented blended learning had. The purpose of this study was therefore to explore how the students of this course could use mobile technology to overcome a shortage of computers. Data from this study have confirmed that mobile technology has a potential to support blended learning beyond classrooms and computer centres. The framework of access to ICT demonstrated that mobile technology increased students' opportunity to access courseware and Facebook. Findings also revealed that social networks such as Facebook improved online communication and increased participation and collaboration beyond the computer centre. The possibility, that access to courseware and communication and collaboration by means of social networks improved learning in the course, suggests further research. A comparative study could be conducted in the same course to determine if there would be any significant difference in learning between students who have access to mobile technology and those who do not.

Recommendations emanating from the findings of this study are that the university should consider establishing wireless networks in student areas such as residences, classrooms and library, to enable students with portable computers to connect to the internet anytime as the need arises; and making the LMS more portable to run on smartphones (by means of a wireless development platform) without compromising the university's internet security.

A limitation of this study is that a small scale sample of students doing one course at this university was used. This research could be extended to a larger sample and possibly across the university, as it could be that a reasonable number of students registered in other courses in the university have mobile devices. Since physical access to computers is still a challenge in South Africa (Czerniewicz \& Brown, 2005), it is possible that this study could influence other contact teaching universities to explore the use of mobile technology for educational purposes. HEIs need to create a more conducive mobile learning environment for students and ensure that lecturers support students to optimally make use of the mobile technology that they have at their disposal.

\section{Acknowledgements}

I thank Dr C Maphosa for mentoring me while I was preparing this paper, and Ms R Masha and Ms E Belcher for language editing of the paper.

\section{References}

Broekman I, Enslin P \& Pendlebury S 2002. Distributive justice and information communication technologies in higher education in South Africa. South African Journal of Higher Education, 16:29-35. 
Brown TH 2003. The role of m-learning in the future of e-learning in Africa. Conference Proceedings, 21st ICDE World Conference, Hong Kong. Available at http://www.tml.tkk.fi/Opinnot/T-110.556/2004/Materiaali/brown03.pdf. Accessed 18 April 2012.

Chen J \& Kinshuk J 2005. Mobile Technology in Educational Services. Journal of Educational Multimedia and Hypermedia, 14:91-107.

Chinn MD \& Fairlie RW 2004. The determinants of the Global Digital Divide: A Cross-Country Analysis of Computer and Internet Penetration. Available at http://escholarship.org/uc/item/76x9876q. Accessed 17 July 2012.

Cobcroft RS, Towers S, Smith J \& Bruns A 2006. Mobile learning in review: Opportunities and challenges for learners, teachers, and institutions. In Proceedings, Online Learning and Teaching (OLT) Conference 2006. Brisbane: Queensland University of Technology. Available at http://eprints.qut.edu.au. Accessed 15 September 2011.

Cochrane T 2009. Using Mobile Web 2.0 to Transform Pedagogy and Engage Learners. New Zealand: Ako Aotearoa Academy of Tertiary Teaching Excellence. Available at http://akoaotearoa.ac.nz/ako-hub/good-practice-publication-grants-e-book. Accessed 25 May 2011.

Creswell JW \& Plano Clark VL 2007. Designing and conducting Mixed Methods Research. USA: Sage Publications.

Czerniewicz L \& Brown C 2005. Access to ICTs for teaching and learning: From single artefact to inter-related resources. International Journal of Education and Development using Information and Communication Technologies, 1:42-56.

Czerniewicz L, Brown C, Lee Pan S \& Moyo A 2008. Students make a plan: ICT access and social and academic uses in higher education. Proceedings of the 6th International Conference on Networked Learning. Available at http://www.nlc.ell.aau.dk/past/nlc2008/abstracts/PDFs/Czerniewicz_69-79.pdf. Accessed 17 July 2012.

Fink C \& Kenny CJ 2003. W(h)ither the Digital Divide? The Journal of Policy, Regulation and Strategy for Telecommunications, Information and Media, 5:15-24.

McDonald A 2009. Facebook in the Classroom: Integration of Online and Classroom Debates into Classes. New Zealand: Ako Aotearoa National Centre for Tertiary Teaching Excellence. Available at http://akoaotearoa.ac.nz/ako-hub/good-practice-publication-grants-e-book. Accessed 25 May 2011.

Meier C 2007. Enhancing intercultural understanding using e-learning strategies. South African Journal of Education, 27:655-671.

Mentz H \& Goosen L 2007. Are groups working in the Information Technology class? South African Journal of Education, 27:329-343.

Motlik S 2008. Mobile Learning in Developing Nations. International Review of Research in Open and Distance Learning, 9:1-7.

Nieuwenhuis J 2010. Qualitative research designs and data gathering techniques. In K Maree (ed.). First steps in research. Pretoria: Van Schaik.

Sharples M, Taylor J \& Vavoula G 2005. Towards a Theory of Mobile Learning. Available at http://www.mlearn.org/mlearn2005/CD/papers/Sharples-\%20Theory \%20of\%20Mobile.pdf. Accessed 19 April 2012.

Van der Westhuizen D 2004. The design and development of a web-based learning environment. In S Gravett \& H Geyser. Teaching and learning in higher education. Pretoria: Van Schaik. 